Colloquia Litteraria

UKSW

$2 / 2014$

EWANGELINA SKALIŃSKA

\title{
„CHIŃSKI NORWID” A MYŚL I POETYKA NORWIDOLOGII POLSKIEJ.
}

[Recenzja książki Krzysztofa Andrzeja Jeżewskiego Cyprian Norwid a myśl i poetyka Kraju Środka ${ }^{1}$ ]

- Dzikość bowiem stąd pochodzi

Że jest się jednostronn y m jak kwiatów korzenie, I że się przeciw-wrotnych połowic nie godzi.

Cyprian Norwid, Dwa guziki (z tyłu)

Esej sinologiczny o Norwidzie - tak brzmi tytuł najbardziej poważnej jak dotąd recenzji książki Krzysztofa Andrzeja Jeżewskiego ${ }^{2}$. Pozycja ta budzi wiele zastrzeżeń recenzentki, Agnieszki Komorowskiej, która zwraca uwagę przede wszystkim na eseistyczny charakter pracy Jeżewskiego (to - zdaje się - jest jej pierwszy i najbardziej podstawowy zarzut), nieścisłości faktograficzne, dotyczące potencjalnej znajomości Norwida kultury chińskiej, braki w literaturze przedmiotu oraz błędy o charakterze korektorskim.

Większość zarzutów Agnieszki Komorowskiej jest raczej słuszna. Natomiast warto zauważyć, że w eseju naukowym Jeżewskiego jest coś niezwykle uwodzącego intelektualnie i inspirującego interpretacyjnie. Nawet jeśli norwidologiczne „szkiełko i oko” może dopatrzeć się w nim rozmaitych uchybień, to jednak warto bardzo mocno podkreślić pozytywne aspekty tak szeroko i ciekawie zakrojonej pracy, przeprowadzonej przez autora - wszak - niebędącego typowym

\footnotetext{
1 Warszawa 2011.

2 Zob. Agnieszka Komorowska, Esej sinologiczny o Norwidzie, „Studia Norwidiana” 2014, nr 29.
} 
norwidologiem, a już na pewno niewikłającego się w uciążliwe spory norwidologiczne.

Tak więc na pierwsze, narzucające się czytelnikowi książki Jeżewskiego pytanie: „Co ma Norwid do Chin?”, badacz spokojnym tonem, pozbawionym jakichkolwiek nut rewelacji, przekonuje, że twórczość Norwida łączy z Chinami naprawdę sporo.

Prezentowana książka zaskakuje. Przecież sylwetka autora Quidama wydaje się być już dobrze przebadana, w końcu co roku $\mathrm{w}$ rozmaitych ośrodkach naukowych powstaje sporo poświęconych Norwidowi publikacji ${ }^{3}$. Wydawać by się mogło, że w tym momencie można jedynie dążyć do coraz lepszego, gruntowniejszego rozumienia tekstów autora Vade-mecum. A tu się okazuje, że istnieje w jego twórczości szereg wątków niedocenionych przez dotychczasowych badaczy.

Urzekający jest prosty, bezpretensjonalny sposób, w jaki pisze Jeżewski o swoim - jakże ważnym - odkryciu norwidologicznym:

Docieramy tutaj do nader interesującego problemu, a mianowicie prawdopodobieństwa wpływu filozofii i estetyki chińskiej na sztukę i myśl autora Vade-mecum. Czy nie tu właśnie należy szukać źródła jej niezwykłej oryginalności? „Ja od żadnego poety polskiego z żywych i umarłych nigdy nic nie wziąłem..." - pisał do Bronisława Zaleskiego w styczniu 1868 roku. Poeta czytał w dwunastu językach i „język chiński nie był mu obcy”, jak pisze w liście do Józefa Ignacego Kraszewskiego z 28 października 1876 roku, a jego pisma świadczą o zdumiewającej jak na owe czasy znajomości cywilizacji Kraju Środka. W jego Albumie Orbis (rodzaj notatnika bogato ilustrowanego przez autora) znajdujemy wiele passusów poświęconych myśli chińskiej i jej pokrewieństwom z chrześcijaństwem ${ }^{4}$.

\footnotetext{
3 Warto w tym miejscu zwrócić uwagę chociażby na jedną z ostatnich prac Piotra Chlebowskiego Romantyczna silva rerum. O Norwidowym «Albumie Orbis», Lublin 2009.

${ }^{4}$ Krzysztof A. Jeżewski, Cyprian Norwid a myśl i poetyka Kraju Środka, dz.cyt., s. 14 .
} 
Nawet jeżeli spojrzymy na powyższy cytat z pewnym dystansem; jeżeli wytkniemy autorowi pewne wyolbrzymienie zagadnienia: Norwid a kultura Chin; jeżeli zdecydowanie podważymy tezę Jeżewskiego o kulturze chińskiej jako źródle „niezwykłej oryginalności" Norwida, to mimo wszystko w tak zaprezentowanym problemie badawczym, w tym komparatystycznym zbliżeniu zostanie ziarno pomysłu równie odważnego, co inspirującego.

Jeżewski prezentuje w książce wynik swojego wieloletniego śledztwa - cierpliwie i sukcesywnie gromadzone ślady obecności chińskiej kultury w pismach Norwida. Z tego eseju możemy dowiedzieć się, gdzie i kiedy autor Milczenia miał okazję zetknąć się z opisami Chin czy też z tłumaczeniem świętych ksiąg Kraju Środka, a także co o nich sądził. W których fragmentach swojej twórczości aktualizował tę tradycję i co w niej szczególnie cenił.

Poszukiwania Jeżewskiego opierają się głównie na różnego rodzaju wspomnieniach Norwida dotyczące kultury chińskiej. Przytaczane przez badacza cytaty są - rzeczywiście - przekonujące ${ }^{5}$. Podaje on też szereg źródeł bibliograficznych, z których (z dużym prawdopodobieństwem) mógł Norwid zaczerpnąć sporo wiadomości na temat Chin. Powstaje tu jednak pewna wątpliwość natury diachronicznej. Jeżewski zdaje się rozciągać wpływ kultury Kraju Środka na całą twórczość autora Vade-mecum, upatrując w niej jedno z podstawowych źródeł oryginalności poety. Jednak nawet pobieżne prześledzenie wymienianych przez Jeżewskiego cytatów z Norwida wyraźnie wskazuje, że bliższa znajomość poety z kulturą Chin rozpoczyna się chyba nie wcześniej niż w roku $1856 \ldots$

Naturalną koleją rzeczy rodzi się pytanie, w jaki sposób nasze rozumienie Norwida może zostać pogłębione przez adaptację na gruncie literaturoznawstwa polskiego proponowanej przez Jeżewskiego analogii.

\footnotetext{
5 Jeżewski podaje, między innymi, taki cytat z Albumu Orbis: „Siła i prawo rezystencji w dziejach: Chiny i Indie - nieruchomość w potędze cnoty - mądrości [...] To upotęgowanie człowieka przez spójnię świętości i mądrości jego z mocami stworzenia właściwą jest cechą całej filozofii orientalnej” (Jeżewski, dz.cyt., s. 17).
} 
Przede wszystkim warto zwrócić uwagę na ogromną wagę spotkania kultur, do którego dochodzi w twórczości Norwida. Nie od dziś wiadomo, że ten najmłodszy romantyk dążył do rozszerzenia ram kultury polskiej, do wyprowadzenia jej z kręgu „parafiańszczyzny”, do ukazania Polakom XIX-wiecznym horyzontu myślowego całej kultury europejskiej z jej bogactwem duchowym i etycznym. Jednak chyba nigdy wcześniej nie sądzono, że głęboki etycyzm Norwida może być związany z etyką i duchowością Wschodu. Jeżewski pisze w tym kontekście o zbliżonym „diapazonie duchowym” polskiego poety i Konfucjusza czy Lao-Tsego.

Jednocześnie autor omawianej książki cały czas doskonale pamięta o fundamentalnych różnicach między osobową, zindywidualizowaną stroną chrześcijaństwa a swoistą „bezosobowością” buddyzmu. Co ciekawe, różnica ta, która na gruncie religijnym wydaje się być ostatecznie nie do pokonania, pod piórem Norwida pozostaje niemal niezauważalna. Bo też - jak świetnie pokazuje to Jeżewski - nie chodzi poecie o to, żeby podejmować dyskusję z kulturą Dalekiego Wschodu, ale o to, żeby czerpać z niej to, co najbardziej wartościowe, co może znacząco wzbogacić albo też skutecznie zrewitalizować kulturę europejską.

Osobne miejsce zajmuje ciekawa refleksja Jeżewskiego nad możliwym wpływem Konfucjusza na Norwidowe poszukiwania językowe: „[wiersz] Ogólniki kończy się słynną dewizą: «Odpowiednie dać rzeczy słowo!». Otóż jest to jedna z zasad Konfucjusza (por. Lun-jü XIII, 3), która polega na «naprawianiu nazw», czyli uściśleniu, uprawidłowieniu sensu słów, na skorygowaniu desygnatów, na «daniu odpowiedniego słowa». «Jeżeli nazwy nie są poprawne, słowa nie odpowiadają prawdzie», mówi Mistrz. Myśl ta została przejęta przez cesarza Cze hoang ti, który kazał wyryć na stelach: «Przyniosłem ład dla tłumów i poddałem próbie czyny i realia: rzecz każda ma nazwę, która jej odpowiada"6.

Zresztą chyba największym i najbardziej wartościowym odkryciem Jeżewskiego jest

${ }^{6}$ Krzysztof A. Jeżewski, dz.cyt., s. 23-24. 
zestawienie Norwidowej poetyki białego kwiatu z rdzennie chińskim estetycznym pojęciem „m d ła o o ś ci”.

Polska „norwidologia” już od wielu lat poszukuje odpowiednich pojęć do opisu Norwidowej poetyki „białego kwiatu” i „dagerotypu”. W kontekście dyptyku Białe kwiaty - Czarne kwiaty (z braku innych narzędzi) badacze zwykle posługują się własnymi określeniami poety: słowa „białe”, „błahe”, „ciche”, „nieobecność stylu” etc. ... Dotychczas można było sądzić, że poetyka obu zbiorków bezprecedensowo zapowiadała estetykę symbolizmu albo minimalizmu. Jeżewski ukazuje tu arcyciekawy kontekst:

To zjawisko [...] typowo chińskie [...] polega na wytłumieniu ekspresji, na przemawianiu półgłosem, operowaniu półtonem, na przemykaniu cichaczem, niemal po kryjomu. Ale jest to proceder równie złożony, co subtelny. Z punktu widzenia semiologii znak "mdławy” w poezji chińskiej nie tyle „przedstawia”, co „od-przedstawia”, bogactwo (wirtualne) mdławości bowiem łączy się z intuicją indywidualną egzystencji z całym jej oderwaniem od zjawisk i świadomością „pustki” właściwej rzeczom [...].

A trochę dalej przytacza Jeżewski opinię francuskiego sinologa, Françoisa Julliena:

W tym stadium rzeczywistość nie jest już „zablokowana” w swych przejawach stronniczych lub zbyt widocznych; konkret staje się dyskretny, otwiera się na przemianę [...] Prowadząc nas do granic wrażliwości, tam gdzie ona znika i rozprasza się, mdławość pozwala nam zaznać „tamtej strony”. Ale ta transgresja nie wychodzi na tamten świat, o statucie metafizycznym, odcięty od wszelkiego doznania. Rozpościera ona tylko ten tutaj (jedyny) - ale oczyszczony z tego, co go zamąca, wirtualny, nastawiony - bez końca - na rozkosze zmysłów ${ }^{7}$.

7 Krzysztof A. Jeżewski, dz.cyt., s. 41. 
Autor analizowanej rozprawy nie poświęca szczególnej uwagi przedstawionemu tu zagadnieniu, traktując je na równi z innymi rozpoznanymi przez siebie znakami obecności kultury Kraju Środka w pismach Norwida. Wydaje się jednak, że właśnie ta obserwacja jest w całej książce najbardziej wartościowa pod względem poznawczym. Wszak metafora „mdławości” (łącznie z jej paradoksalnym aksjologicznie „znakiem ujemnym”) zdaje się blisko przylegać do sedna poetyki i filozofii Norwidowych Kwiatów, w których możemy przeczytać:

Jeżeli mówię: cisze różne, to i w y r a z y one białe, bezmyślne, nie opowiadające nic, a których kilka tu i owdzie słyszałem, albo którym raczej świadkiem byłem, bo od tła, na którym miejsca swe znajdowały, nieodłącznymi są ${ }^{8}$.

„Wyrazy białe, bezmyślne”, a za Jeżewskim powiedzielibyśmy - „mdławe”, stają się znakiem, ale nie zwykłym znakiem, który na zasadzie referencji łączy się z rzeczywistością, ale znakiem - ledwo uchwytnym, półprzezroczystym, ledwie sugerującym możliwość rozumienia. Zresztą może nie tyle stricte rozumienia, co właśnie możliwości pewnej kontemplacji rzeczywistości.

Rozprawa Cyprian Norwid a myśl i poetyka Kraju Środka charakteryzuje się jeszcze jedną ciekawą cechą - obszernym materiałem egzemplifikacyjnym. O ile pierwszą część książki można określić mianem eseju komparatystycznego, o tyle jej druga część jest wyborem z Vade-mecum Norwida, opatrzonym licznymi - często zaskakującymi - kontekstami, ukazującymi myśl poety na tle kultury powszechnej.

Doskonałym tego przykładem jest chociażby ukazanie liryku Jak... - subtelnego wiersza miłosnego - w europejsko-wschodnim kontekście filozoficzno-estetycznym. Całość Norwidowego liryku opiera się na „akwarelowym” szkicu sytuacji spotkania z ukochaną.

\footnotetext{
${ }^{8}$ Cyprian Norwid, Białe kwiaty, w: tenże, Pisma wszystkie, zebrał, tekst ustalił, wstępem i uwagami krytycznymi opatrzył Juliusz W. Gomulicki, t. VI: Proza, Warszawa 1977, s. 192.
} 
Jego zmysłowość jest do tego stopnia subtelna, że wykracza poza ramy cielesne i przenosi się w dziedzinę ducha. Zresztą na płaszczyźnie konstrukcyjnej utworu mamy do czynienia właśnie z takim chińskim „mdławym” znakiem uczucia - z uczuciem zasugerowanym za pomocą szeregu obrazów sytuacji, które składają się na całość nienazwanego, bo (być może) nienazywalnego uczucia. Wiersz kończy się słowami: „..lecz nie rzeknę nic - bo jest mi smętno”, które doskonale korespondują z przywołanym przez Jeżewskiego fragmentem z Czuang-tsego:

Słowa swobodnie płynące [jak wino z dzbana] są odbiciem natury. Ponieważ rozchodzą się szeroko, trwają bez końca. Niemówienie oznacza zgodność [ale ta] zgodność nie jest zgodna ze swoim określeniem, a jej określenie nie jest zgodne z tą zgodnością. Dlatego powiedziane jest: nie wyrażajcie się słowami. Gdy człowiek mówi nie mówiąc, to choćby mówił całe życie, to jak gdyby się nie odezwał ani słowem; choćby przez całe życie nie odezwał się ani słowem, jest to jak gdyby stale mówił?.

Należy mocno podkreślić jeszcze jedną zaletę tej specyficznej antologii, która nie tylko rozszerza konteksty interpretacyjne Vade-mecum, ale też staje się pewnym rodzajem otwartej, ciągle stającej się na nowo interpretacji. Jeżewski z reguły nie proponuje tu żadnego własnego rozumienia tekstów Norwida, ale daje czytelnikowi doskonałe narzędzia do tworzenia własnych ciągów skojarzeń.

Naturalnie wypada wspomnieć także o tym, że metoda takiego opracowania Vade-mecum ma swój wyraźny pierwowzór w edytorskich pracach Józefa Ferta ${ }^{10}$. Jednak o ile badacz lubelski dąży - jak się zdaje - do symbolicznego „skodyfikowania” lektury, do sprecyzowania sensów i ustalenia siatki powiązań myślowych w obrębie

\footnotetext{
9 Krzysztof A. Jeżewski, dz.cyt., s. 94.

10 Cyprian Norwid, Vade-mecum, oprac. Józef Fert, BN I 271, Wrocław-Kraków 1999. W wersji obszerniejszej: Cyprian Norwid, Vade-mecum, oprac. Józef Fert, Lublin 2004 .
} 
twórczości autora Assunty, o tyle propozycja Jeżewskiego dąży do jej „otwarcia” na inny wymiar kulturowy.

Ta podstawowa różnica w podejściu do Norwida Jeżewskiego i większości polskich norwidologów przejawia się również w sposobie prowadzenia wywodu. Jeżewski rezygnuje z obciążeń stylu naukowego, przez co lektura jego książki nie tylko wnosi sporo nowego do naszego rozumienia Norwida, ale też sprawia zwyczajną przyjemność i pozwala wyraźnie dostrzec powody, dla których Norwid jest uznawany za jednego z największych XIX-wiecznych poetów europejskich.

\section{Summary \\ Ewangelina Skalińska, „Chinese Norwid” and the thought and poetics of Polish Norwid studies}

Review of Krzysztof Andrzej Jeżewski, Cyprian Norwid a myśl i poetyka Kraju Środka [Cyprian Norwid and the thought and poetics of the Middle Kingdom].

The review discusses main research questions tackled by Krzysztof Andrzej Jeżewski, the author of a comparative essay that juxtaposes selected aspects of Chinese culture and aesthetics with Cyprian Norwid's works. 